Article Type: Brief Communication

\title{
Time for global scale-up, not randomized trials, of uterine balloon tamponade for postpartum hemorrhage
}

Thomas F. Burke ${ }^{1,{ }^{\star}}$, Kusum Thapa ${ }^{2}$, Poonam Shivkumar ${ }^{3}$, Vincent Tarimo ${ }^{4}$, Monica Oguttu ${ }^{5}$, Lorraine Garg ${ }^{1}$, Saroja Pande ${ }^{2}$, Juzar Fidvi ${ }^{6}$, Vidyadhar Bangal ${ }^{7}$, José Ochoa ${ }^{8}$, Archana Amatya $^{2}$, Melody Eckardt ${ }^{1}$, Apollinaire Horo ${ }^{9}$, Khama Rogo ${ }^{10}$, Kshama Kedar ${ }^{11}$, Albert Manasyan ${ }^{12}$, Pragati Khalatkar ${ }^{13}$, Susana $\mathrm{Ku}^{14}$, Anders Seim ${ }^{15}$, Sebastian Suarez ${ }^{1}$, Moytrayee Guha ${ }^{1}$, Khadija Abdalla ${ }^{16}$, Carlos Fuchtner ${ }^{17}$, Maria F. Escobar ${ }^{18}$, Sabaratnam Arulkumaran $^{19}$

${ }^{1}$ Division of Global Health and Human Rights, Department of Emergency Medicine, Massachusetts General Hospital, Boston, MA, USA

${ }^{2}$ Nepal Society of Obstetricians and Gynaecologists (NESOG), Propokar Maternity and Women's Hospital, Thapathali, Kathmandu, Nepal

${ }^{3}$ Department of Obstetrics and Gynecology, Mahatma Gandhi Institute for Medical Sciences, Wardha, Maharashtra, India

${ }^{4}$ Department of Obstetrics and Gynecology, Muhimbili National Hospital, Dar es Salaam, Tanzania

${ }^{5}$ Kisumu Medical and Education Trust (KMET), Kisumu, Kenya

${ }^{6}$ Department of Obstetrics and Gynecology, Vidarbha Institute of Medical Sciences, Nagpur, Maharashtra, India

${ }^{7}$ Department of Obstetrics \& Gynecology, Rural Medical College, Pravara Institute of Medical Sciences (Deemed University), Maharashtra, India

${ }^{8}$ Department of Obstetrics and Gynecology, Hospital General San Felipe, Tegucialpa, Honduras

${ }^{9}$ Department of Obstetrics and Gynecology, Teaching Hospital of Yopougon, Abidjan, Côte d'Ivoire

${ }^{10}$ African Institute for Health Transformations, Sagam Community Hospital, Luanda, Kenya

${ }^{11}$ Department of Obstetrics and Gynecology, Indira Gandhi Government Medical College, Nagpur, Maharashtra, India

${ }^{12}$ Division of Pediatric Neonatology, Department of Pediatrics, The University of Alabama at Birmingham Hospital, Birmingham, AL, USA

This article has been accepted for publication and undergone full peer review but has not been through the copyediting, typesetting, pagination and proofreading process, which may lead to differences between this version and the Version of Record. Please cite this article as doi: 10.1002/ijgo.12492

This article is protected by copyright. All rights reserved. 
${ }^{13}$ Khalatkar Hospital Paediatric Maternity and Surgical Hospital, Nagpur, Maharashtra, India

${ }^{14}$ Midwifery Services of Lambton-Kent, Bluewater Health Hospital, Sarnia, ON, Canada

${ }^{15}$ Health \& Development International, Fjellstrand, Norway

${ }^{16}$ United Nations Children's Fund, UNICEF Kenya Country Office, Nairobi, Kenya

${ }^{17}$ International Federation of Gynecology and Obstetrics (FIGO), London, UK

${ }^{18}$ Department of Obstetrics and Gynecology, Fundacion Valle del Lili, Cali, Colombia

${ }^{19}$ Department of Obstetrics and Gynecology, St. George's University of London, London, UK

\section{${ }^{*}$ Correspondence}

Thomas F. Burke, Division of Global Health and Human Rights, Department of Emergency Medicine, Massachusetts General Hospital, Boston, MA, USA

Email: tfburke@mgh.harvard.edu

KEYWORDS: Clinical equipoise; Global scale-up; Low-resource settings; Maternal mortality; Postpartum hemorrhage; Randomized controlled trial; Uterine balloon tamponade

Maternal death is the greatest health disparity globally, with postpartum hemorrhage the most common cause. As senior leaders in obstetrics and maternal health from Bolivia, Canada, Colombia, Côte d'Ivoire, Honduras, India, Kenya, Nepal, Niger, Norway, Peru, Tanzania, the UK, the USA, and Zambia, we are deeply disturbed by recent calls for randomized controlled trials (RCTs) of uterine balloon tamponade (UBT) in women with uncontrolled postpartum hemorrhage (PPH). Our collective experience, in combination with mounting evidence, unequivocally supports the effectiveness of commercial and condom UBTs in averting death and disability from $\mathrm{PPH}$ associated with atonic uterus. We believe it would be highly unethical to embark on an RCT of UBT, now or in the future, unless compared with a proven equivalent intervention.

Uterine balloon tamponade was first described 35 years ago as a method to arrest PPH from an atonic uterus. Since then, a growing body of evidence supports the efficacy of this approach. For example, in a series of women with uncontrolled hemorrhage refractory to all other interventions, 160 (98\%) of 163 survived after placement of a pre-packaged condom uterine balloon [1]. Additionally, among 306 consecutive women with uncontrolled PPH across 117 facilities, the survival rate was $99.4 \%$ if the UBT device was placed before advanced shock (objective signs of neurological and/or cardiovascular compromise) [2]. Other evidence includes independently performed near-miss surveys, impact and costeffectiveness studies, and the experiences of senior obstetricians' and midwives' in averting deaths and hysterectomies from their 14 countries and beyond (Table 1). UBT has also This article is protected by copyright. All rights reserved. 
influenced surgeons' behavior by averting emergency hysterectomies [3]. Overall, the evidence supports a high degree of efficacy of UBT use among women with PPH in lowresource settings around the world.

An RCT can only be ethically embarked upon if the condition of equipoise is met. By definition, equipoise is present if and only if science and experience have yet to reveal whether an intervention in question causes more good or more harm than alternative approaches. We stand together in confident solidarity and declare that, based on the current evidence generated from both empirical [4] and hypothesis-driven research, there is no equipoise in the case of UBT for PPH from an atonic uterus. Therefore, global scale-up of UBT and other effective and affordable interventions should be accelerated in an effort to end the scourge of unnecessary death and disability from $\mathrm{PPH}$.

\section{Author contributions}

TFB led development of the manuscript. All other authors contributed equally in reviewing and editing the manuscript.

\section{Conflicts of interest}

The authors have no conflicts of interests

\section{References}

[1] Burke TF, Ahn R, Nelson BD, et al. A postpartum haemorrhage package with condom uterine balloon tamponade: a prospective multi-centre case series in Kenya, Sierra Leone, Senegal, and Nepal. BJOG. 2016;123:1532-1540.

[2] Burke TF, Danso-Bamfo S, Guha M, Oguttu M, Tarimo V, Nelson BD. Shock progression and survival after use of a condom uterine balloon tamponade package in women with uncontrolled postpartum hemorrhage. Int J Gynecol Obstet. 2017;139:34-38.

[3] Pendleton AA, Natarajan A, Ahn R, Nelson BD, Eckardt MJ, Burke TF. A qualitative assessment of the impact of a uterine balloon tamponade package on decisions regarding the role of emergency hysterectomy in women with uncontrolled postpartum haemorrhage in Kenya and Senegal. BMJ Open. 2016;6:e010083.

[4] Craig P, Dieppe P, Macintyre S, Michie S, Nazareth I, Petticrew M. Developing and evaluating complex interventions: the new Medical Research Council guidance. BMJ. 2008;337:a1655.

This article is protected by copyright. All rights reserved. 
Table 1 Quotes from 2017 OBGyn meetings

\begin{tabular}{|c|c|}
\hline $\begin{array}{l}\text { Poonam Shivkumar; Chief of } \\
\text { ObGyn, Department of } \\
\text { Obstetrics and Gynecology, } \\
\text { Mahatma Gandhi Institute for } \\
\text { Medical Sciences, India }\end{array}$ & $\begin{array}{l}\text { "My first case of UBT was a sudden massive hemorrhage post C- } \\
\text { section. BP was } 40 \text { palpable and then no pulse or BP. UBT } \\
\text { immediately stopped her bleeding and we brought her back. She } \\
\text { was discharged } 1 \text { week later." } \\
\text { "MVA was performed for retained placental tissue with } \\
\text { associated hemorrhage. Despite MVA and maximum uterotonics, } \\
\text { pouring of blood worsened. She collapsed and a UBT was } \\
\text { placed. Bleeding stopped instantly and she was discharged in } \\
\text { three days." }\end{array}$ \\
\hline $\begin{array}{l}\text { Kshama Kedar; Senior } \\
\text { ObGyn, Department of } \\
\text { Obstetrics and Gynaecology, } \\
\text { Indira Gandhi Government } \\
\text { Medical College, India }\end{array}$ & $\begin{array}{l}\text { "Sudden hemorrhage } 2 \text { hours post C-section. Raced her to the } \\
\text { OT and placed a UBT while prepping her. Bleeding arrested and } \\
\text { no surgery needed" } \\
\text { "In the year before ESM-UBT TM we did eight hysterectomies for } \\
\text { PPH. We have done none for } 10 \text { months" }\end{array}$ \\
\hline $\begin{array}{l}\text { Vidyadhar Bangal; Chief of } \\
\text { ObGyn, Department of } \\
\text { Obstetrics \& Gynecology, } \\
\text { Rural Medical College, } \\
\text { Pravara Institute of Medical } \\
\text { Sciences (Deemed } \\
\text { University), India }\end{array}$ & $\begin{array}{l}\text { "We have saved } 14 \text { women from open procedures with UBT this } \\
\text { year" } \\
\text { "We did seven or eight hysterectomies for PPH last year, prior to } \\
\text { UBT. We have only done one this year" }\end{array}$ \\
\hline $\begin{array}{l}\text { José Ochoa; Chief of ObGyn, } \\
\text { Department of Obstetrics and } \\
\text { Gynecology, Hospital } \\
\text { General San Felipe, } \\
\text { Tegucialpa, Honduras }\end{array}$ & $\begin{array}{l}\text { "Massive hemorrhage soon after delivery, the very evening after } \\
\text { we were first trained. Quickly moved her to the OT. Placed a UBT } \\
\text { and wow, we did not need to operate." }\end{array}$ \\
\hline $\begin{array}{l}\text { Apollinaire Horo; Senior } \\
\text { ObGyn, Department of } \\
\text { Obstetrics and Gynecology, } \\
\text { Teaching Hospital of } \\
\text { Yopougon, Côte d'Ivoire }\end{array}$ & $\begin{array}{l}\text { "I was very skeptical. I am a gynecology oncologist but cover } \\
\text { deliveries. But, since UBT training I had two severe emergency } \\
\text { cases that converted me. They were both too far gone to go to } \\
\text { the operating room, but we saved them with the UBT" }\end{array}$ \\
\hline $\begin{array}{l}\text { Saroja Pande; General } \\
\text { Secretary of Nepal Society of } \\
\text { Obstetricians and }\end{array}$ & $\begin{array}{l}\text { "I have used the condom UBT over } 50 \text { times. It absolutely saves } \\
\text { lives and avoids surgery" }\end{array}$ \\
\hline
\end{tabular}

This article is protected by copyright. All rights reserved. 


\begin{tabular}{|c|c|}
\hline $\begin{array}{l}\text { Gynaecologists (NESOG), } \\
\text { Paropakar Maternity and } \\
\text { Women's Hospital, Nepal }\end{array}$ & \\
\hline $\begin{array}{l}\text { Kusum Thapa; President } \\
\text { Nepal Society of } \\
\text { Obstetricians and } \\
\text { Gynaecologists (NESOG) } \\
\text { and Senior Officer for the } \\
\text { Jhpiego Maternal \& Child } \\
\text { Survival Program, WA, DC } \\
\text { USA }\end{array}$ & $\begin{array}{l}\text { "I brought UBT to Kathmandu over } 10 \text { years ago from } \\
\text { Bangladesh. My colleagues and I have saved many many lives } \\
\text { with it" }\end{array}$ \\
\hline $\begin{array}{l}\text { Vincent Tarimo; Chief of } \\
\text { ObGyn, Department of } \\
\text { Obstetrics and Gynecology, } \\
\text { Muhimbili National Hospital, } \\
\text { Tanzania }\end{array}$ & $\begin{array}{l}\text { "The UBT has saved so many women since we started in April of } \\
\text { 2016. We now have a problem training our residents in } \\
\text { emergency hysterectomy because they are not needed very } \\
\text { often any longer" }\end{array}$ \\
\hline $\begin{array}{l}\text { Monica Oguttu, Executive } \\
\text { Director of Kisumu Medical } \\
\text { and Education Trust (KMET) } \\
\text { and senior nurse midwife, } \\
\text { Kenya }\end{array}$ & $\begin{array}{l}\text { "You cannot believe the stories of midwives saving the lives of } \\
\text { women because of UBT. It is called the magic device" }\end{array}$ \\
\hline
\end{tabular}

Abbreviations: ObGyn, obstetrics and gynecology. UBT, uterine balloon tamponade. BP, blood pressure. MVA, manual vacuum evacuation. OT, operating theater. ESM-UBT, Every Second Matters for Mothers and Babies ${ }_{\mathrm{TM}}-\mathrm{UBT}$. PPH, postpartum hemorrhage.

This article is protected by copyright. All rights reserved. 